\title{
Patient reluctance to accept Do Not Resuscitate order: impact on clinical care
}

Amal Al Farhan, ${ }^{1}$ Manal Al Harthi, ${ }^{2}$ Manerh Bin Mosa, ${ }^{3}$ Afaf Moukaddem, ${ }^{4}$ Hamdan Al Jahdali, ${ }^{5}$ Jinan Shamou, ${ }^{6}$ Abdulla Al Sayyari ${ }^{7}$ and Salim Baharoon ${ }^{8}$

${ }^{1}$ Department of Anaesthesia, King Abdulaziz Medical City, National Guard Health Affairs, Riyadh, Saudi Arabia. ${ }^{2}$ Department of Obstetrics and Genecology, King Abdulaziz Medical City, National Guard Health Affairs, Riyadh, Saudi Arabia. ${ }^{3}$ Department of Urology, King Abdulaziz Medical City, National Guard Health Affairs, Riyadh, Saudi Arabia. ${ }^{4}$ Department of Medical Education, College of Medicine, King Saud Bin Abdulaziz University for Health Sciences, Riyadh, Saudi Arabia. ${ }^{5}$ Department of Medicine, Pulmonary Division, King Abdulaziz Medical City, National Guard Health Affairs, Riyadh, Saudi Arabia. ${ }^{6}$ Xi'an Jiaotong University, China. ${ }^{7}$ Department of Medicine, Nephrology \& Renal Transplantation Division, King Abdulaziz Medical City, Riyadh, Saudi Arabia. ${ }^{8}$ Department of Critical Care, King Abdulaziz Medical City, National Guard Health Affairs, Riyadh, Saudi Arabia (Correspondence to: S. Baharoon: baharoon@hotmail.com).

\begin{abstract}
Background: A Do Not Resuscitate (DNR) order should only impede the performance of cardiopulmonary resuscitation in case of cardiac or respiratory arrest; it should not interfere with any other treatment decisions.

Aims: To study the impact of DNR order placement on daily clinical care of patients.

Methods: This was a retrospective cohort study of 72 patients in a tertiary care centre in Saudi Arabia. Daily clinical care measures were collected for 2 weeks prior and 2 weeks after DNR order placement and included vital signs, nursing care, comfort measures, documentation, visits by senior and junior physicians, and tests completed.

Results: Malignancy was the most common diagnostic category (43.1\%). There was a significant reduction in vital signs documentation, tests completed, documentation, and visits by physicians after DNR orders, with no change in nursing care and comfort measures. No differences were seen for place of DNR order (intensive care unit vs medical ward), category of disease, or sex, but there were differences for documentation (more in females) and vital signs (more in males). More vital signs were documented and more tests were done in patients who survived compared to those who died. Regression analysis showed that the frequency of post-DNR order vital signs measurements and investigations done was not related to sex, age, diagnosis, time from admission to DNR order, or location of patients. Time to death was only related to sex and post-DNR order summary documentation.
\end{abstract}

Conclusions: Placement of DNR orders significantly reduced vital signs measurements, investigations done, documentation and visits by physicians but not nursing care and comfort measures.

Keywords: clinical care, Do Not Resuscitate order, patient reluctance, Saudi Arabia

Citation: Al Farhan A; Al Harthi M; Bin Mosa M; Moukaddem A; Al Jahdali H; Shamou J; et al. Patient reluctance to accept Do Not Resuscitate order: impact on clinical care. East Mediterr Health J. 2020;26(8):933-938. https://doi.org/10.26719/emhj.20.009

Received: 26/05/18; accepted: 30/04/19

Copyright ( ) World Health Organization (WHO) 2020. Open Access. Some rights reserved. This work is available under the CC BY-NC-SA 3.0 IGO license (https://creativecommons.org/licenses/by-nc-sa/3.o/igo).

\section{Introduction}

According to the President's Commission for the Study of Ethical Problems in Medicine and Biomedical and Behavioral Research, a Do Not Resuscitate (DNR) order should only impede the performance of cardiopulmonary resuscitation in case of cardiac or respiratory arrest; it should not interfere with any other treatment decisions. Placing a patient on a DNR order, however, may have significant implications for various aspects of clinical care and mortality (1).

Patients hospitalized with acute heart failure who have a DNR order placed are less likely to have their left ventricular function evaluated or be given beta blockers or anticoagulants (2). DNR orders in hospitalized patients are significantly associated with patients' age, social dependence and diagnosis of malignancy or acute stroke (3).

A study in the United Kingdom of Great Britain and Northern Ireland compared the level of care provided to stroke patients with and without a DNR order and concluded that the former received a lower level of care as they were less likely to be admitted to a specialized stroke unit (4). Their mortality rate was higher than that of patients with no DNR orders (10\% vs $67 \%$ ).

It is also reported that patients with DNR orders receive different treatments in different hospitals, which affects their outcome. The hospitals with the highest early DNR order rate (adjusted for case mix) had fewer interventions and lower costs per patient. The author concluded that "early care limitation leads to an overall milieu of nihilism that, perhaps unexpectedly, may influence attitudes of care for patients beyond those with the DNR orders themselves".

The impact of DNR orders on care provision has not been adequately investigated worldwide, and to the best of our knowledge it has not been measured in Saudi Arabia. Due to the unique cultural aspects of Saudi Arabia, we cannot assume that the results of international studies are representative of Saudi hospitals. In addition, 
some Saudi hospitals lack regulations to guide the use of DNR orders and their effect on quality of care (5).

This study evaluated the impact of DNR orders on some aspects of care provided for patients at a tertiary care university hospital in Riyadh, Saudi Arabia by comparing the level of care before and after DNR orders.

\section{Methods}

This was a retrospective cohort study on the impact of DNR orders placed by the most responsible physician (MRP). The MRP was not part of the study or aware of it, and his decision was independent of the study. MRP is a term used in our hospital to indicate the consultant physician who has the most responsibility on patient management. The study was conducted in King Abdul-Aziz Medical City (KAMC), Riyadh from March 2016 to June 2017. KAMC is an institution with 260 beds in medical wards. An estimated of 15-20 patients are admitted daily from the emergency room to these wards.

All adult patients placed on a DNR order by the MRP within the data collection period and who had complete files were included, provided that the DNR order was written for at least 1 week. The following patients were excluded: those with DNR orders referred to palliative care; those who died within 48 hours of writing the DNR order; those for whom a DNR order was placed $<1$ week after admission; and those with DNR orders before their current hospitalization.

The medical wards were visited by one of the investigators 3 times a week. On each visit, the charge nurse was asked about new DNR orders on patients. Patients' records were reviewed for the week before and the week after placement of the DNR order.

The variables documented were demographics (age, sex, admission date, DNR date, date of death, and admission diagnosis category) and frequency of daily clinical care measures. The scores were summated into the following categories: (1) frequency of vital signs recording (blood pressure, respiratory rate, and $\mathrm{O}_{2}$ saturation); (2) nursing practice (pain assessment recording, mouth care frequency, and frequency of position changes); (3) comfort measures (pain relief); (4) documentation; (5) frequency of visits by senior physicians; (6) frequency of visits by junior physicians; and (7) recording of tests completed (number of daily blood tests, number of blood product units transfused, number of radiological tests, and number of blood cultures).

The summative "vital signs" mean score was calculated as the mean of the measurement of blood pressure, respiratory rate and $\mathrm{O}_{2}$ saturation pooled together throughout each of the observation periods (preor post-DNR orders). Each of these variables carried the same weight. The summative "comfort and nursing care" mean score was calculated as the mean of the numbers of pain assessments, mouth care, position changes and pain relief measures pooled together throughout each of the observation periods (pre- or post-DNR orders). Each of these variables carried the same weight. The summative "tests completed" mean score was calculated as the mean of the numbers of daily blood tests, blood product units transfused, radiological tests completed, and blood cultures pooled together throughout each of the observation periods (pre- or post-DNR orders). Each of these variables carried the same weight. The summative "senior physicians" mean score was calculated as the mean number of visits by consultants, associate consultants and medical fellows pooled together throughout each of the observation periods (pre- or post-DNR orders). Each of these variables carried the same weight. The summative "junior physicians" mean score was calculated as the mean number of visits by assistant consultants, residents and staff physicians pooled together throughout each of the observation periods (pre- or post-DNR orders). Each of these variables carried the same weight. The scores of pain relief drugs refers to the mean number of times an analgesic drug was given, pooled together throughout each of the observation periods (pre- or post-DNR orders). Each of the drugs given carried the same weight.

Data were analysed using SPSS version 21 and descriptive statistics were generated (mean and standard deviation for continuous variables). Percentages and proportions were calculated for categorical data. Paired samples $t$ test was used to compare the means before and after DNR orders. Independent sample t test was used for the post-DNR order results according to median age, sex and disease category. Regression analysis was performed to assess the independent effect of demographics and underlying diagnosis on patient care and time to death post-DNR order. $P<0.05$ was considered statistically significant.

\section{Results}

Seventy-two patients were included in the study with an average age of 74.4 years and $41(56.9 \%)$ were male. Time from admission to DNR order was 43.5 days. DNR orders were placed at the intensive care unit (ICU) in 20 (27.8\%) cases and at the medical wards in $52(72.2 \%)$ cases. The overall mortality rate was $29.2 \%$ (21 patients) with a mean time from DNR order to death of 43.2 days.

The commonest comorbid conditions were organ failure and bedridden status (both $n=21 ; 29.2 \%$ ) and dementia $(n=9 ; 12.5 \%)$. A total of $33(45.9 \%)$ patients were bedridden (Table 1).

When comparing the whole group for pre- and postDNR order frequency of care measures, we found a highly significant drop in the frequency of measuring vital signs, doing tests, documentation and visits by physicians (Table 2). However, nursing care or comfort measures did not differ and there was more pain relief medication given after DNR order placement.

When comparing post-DNR summative scores in patients below and above the median age, we found no significant differences, except in the comfort measures, which were higher in the older group (Table 3).

When comparing post-DNR summative scores according to sex, we found significant differences in 


\begin{tabular}{lc}
\hline Table 1 Sample participants' characteristics & 72 \\
\hline Number & $74.4(14.4)$ years \\
Age (SD) & $41(56.9 \%)$ \\
$\quad$ Males & $43.5(72.6)$ days \\
Time from admission to DNR order (SD) & $20(27.8 \%)$ \\
Location of DNR order ICU & $52(72.2 \%)$ \\
Medical ward & $12.8(2.4)$ days \\
Pre-DNR order follow up duration (SD) & $13.2(1.9)$ days \\
Post-DNR order follow up duration (SD) & $43.2(43.0)$ days \\
Time from DNR order death (SD) & $21(29.2 \%)$ \\
Overall mortality in DNR patients during study follow-up & \\
Diagnosis category & $9(12.5 \%)$ \\
Dementia & $5(6.9 \%)$ \\
Malignancy & $21(29.2 \%)$ \\
Organ failure & $21(29.2 \%)$ \\
Bedridden & $4(5.5 \%)$ \\
Others & $9(12.5 \%)$ \\
Dementia and bedridden & $3(4.2 \%)$ \\
Malignancy and bedridden &
\end{tabular}

$\mathrm{DNR}=$ Do Not Resuscitate $\mathrm{SD}=$ standard deviation .

only 2 parameters: men had more vital signs measured than women had, and women had more documentation than men had (Table 4). When comparing post-DNR summative scores according to patient survival during the observation period, we found significant differences in only 2 parameters: patients who died had more vital signs measured than those who survived, and those who died had more tests done. Patient sex and disease category did not differ between those who died and those who survived.

Regression analysis showed that the frequency of post-DNR vital sign measurements and investigations done was not related to sex, age, diagnosis, time from admission to DNR order placement, or location of patients. However, age affected post-DNR order comfort measures given $(P=0.0044)$, sex affected post-DNR order frequency of visits by junior staff and frequency of documentation. Time to death was not related to age, diagnosis (except dementia), time from admission to DNR order, location of patients, or post-DNR care given.
However, time to death was related to sex and post-DNR documentation.

\section{Discussion}

DNR orders only mean that there should be no attempt at cardiopulmonary resuscitation and should not mean abandoning other forms of therapy, unless clearly specified. A DNR order does not prevent blood tests, vital sign measurement, nursing care and other services, including ICU admission and ventilation, unless clarified and communicated to patients or their families. All other clinical care measures should be adhered to. In some terminal care patients, however, the DNR order may be a part of a palliative care plan that allows only comfort care measures.

As others have found, when we compared pre- and post-DNR order frequency of care measures, we found a highly significant drop in the frequency of measuring vital signs, investigations, documentation and visits by physicians. However, nursing care or comfort did not

\begin{tabular}{|c|c|c|c|c|}
\hline & $\begin{array}{c}\text { Pre-DNR summative } \\
\text { scorea }\end{array}$ & $\begin{array}{c}\text { Post-DNR summative } \\
\text { scorea }\end{array}$ & $\begin{array}{c}\text { Mean difference } \\
(95 \% \mathrm{CI})\end{array}$ & $\mathbf{P}$ \\
\hline Vital signs & $10.84(5.4)$ & $7.18(2.6)$ & $-3.66(-4.77$ to -2.56$)$ & 0.0001 \\
\hline Comfort and nursing care & $2.08(0.58)$ & $2.26(1.06)$ & $0.18(-0.06$ to 0.41$)$ & 0.13 \\
\hline Pain relief drugs given & $0.1(0.4)$ & $0.4(0.8)$ & $0.3(-0.5$ to -0.1$)$ & 0.003 \\
\hline Laboratory tests & $3.00(1.58)$ & $1.97(0.89)$ & $1.03(1.41$ to 0.65$)$ & 0.0001 \\
\hline Documentation & $3.27(2.34)$ & $2.33(1.19)$ & $0.94(1.32$ to 0.56$)$ & 0.0001 \\
\hline Visits from senior physicians & $0.76(0.25)$ & $0.52(0.22)$ & $-0.24(-0.31$ to -0.17$)$ & 0.0001 \\
\hline Visits from junior physicians & $0.37(0.13)$ & $0.30(0.12)$ & $-0.064(-0.10$ to -0.03$)$ & 0.0007 \\
\hline
\end{tabular}

${ }^{a}$ Values in parentheses are standard deviation. $C I=$ confidence interval; $D N R=$ Do Not Resuscitate $S D=$ standard deviation. 


\begin{tabular}{|c|c|c|c|}
\hline Variables assessed post-DNR & Below median age $^{a}$ & Above median age ${ }^{a}$ & $\mathbf{P}$ \\
\hline Vital signs & $6.67(2.28)$ & $7.72(2.92)$ & 0.15 \\
\hline Comfort & $2.03(0.53)$ & $2.50(1.39)$ & 0.001 \\
\hline Tests completed & $2.08(0.87)$ & $1.85(0.90)$ & 0.84 \\
\hline Documentation & $2.32(1.17)$ & $2.35(1.22)$ & 0.80 \\
\hline Visits from senior physicians & $0.52(0.24)$ & $0.52(0.21)$ & 0.45 \\
\hline Visits from junior physicians & $0.28(0.2)$ & $0.33(0.11)$ & 0.06 \\
\hline
\end{tabular}

${ }^{a}$ Values in parentheses are standard deviation. DNR $=$ Do Not Resuscitate.

differ and there was more pain relief given after DNR order placement compared to before the order $(6,7)$.

When we compared the mean summative scores of patients who died and those who did not during the observation period, we found no differences, except that more vital signs were documented and more tests were done in the group that died. This indicates that the physicians paid more attention only when the patients became seriously ill. However, the sex of the patients and their disease category did not differ according to whether the patients died or not.

These findings are consistent with other international studies reporting a significant change in practice for patients with DNR orders placed early after admission. A study from California, United States of America reported that among 5212 patients admitted after an outof-hospital cardiac arrest, about one third had a DNR order within the first 24 hours. Compared to those who did not have a DNR order, this group of patients had fewer cardiac catheterizations, less blood transfusion, fewer interventions and higher mortality. The authors concluded that DNR orders within 24 hours may have been premature as they were associated with reduced interventions that could have improved outcome. The authors also noted significant differences in the practice between the hospitals studied (8). Patients with DNR orders fare less well in terms of prognosis than those without DNR orders, even after full adjustment for risk factors. Mortality rates are higher in patients with DNR orders compared to patients with similar severity of illness and comorbidity but without DNR orders in place $(9,10)$. A study of $>15000$ trauma patients found that DNR status and not age affected the post-injury outcome (11). However, Chu et al., in a review of the influence of DNR orders on patient care in adult ICUs, could not identify a direct impact of DNR orders on patient care (12).

In our patient population the drop in care after DNR was seen only among physicians rather than nurses. This may be because nursing care is usually more protocolled or that nursing assessment is more closely monitored by charge nurses in the unit and fellow nurses on the next shifts. It also may be down to cultural factors as most nurses are expatriates and are more committed due to fear for their jobs. Physicians, however, especially junior physicians may mistake the concept of DNR with comfort care only. The increase in analgesic prescription could reflect their notion of DNR meaning only to comfort patients and not to address their actual complaints.

There are only sparse data addressing nursing care after DNR order placement. The role of nursing in DNR orders and care planning and nursing workloads after DNR order placement have been addressed, but only a few studies have investigated the actual level of nursing care delivered $(13,14)$. Henneman et al. reported that nurses stated that they would be significantly less likely to perform a variety of physiological monitoring procedures and interventions for patients with a DNR order than for patients without such an order (15).

This drop in post-DNR order care with resultant unintended harmful consequences has caused many hospitals to adopt an alternative approach to DNR orders. The Universal Form of Treatment Options (UFTO) is one of these alternatives. UFTO has resulted in a significant reduction in harmful events in patients with DNR orders, indicating that it has improved care for this group of patients (16). Others have replaced the DNR order with care plans of comfort and supportive care to eliminate misunderstanding attached to the order (17).

Table 4 Comparing post-DNR summative scores by sex and whether patients died or survived

\begin{tabular}{|c|c|c|c|}
\hline \multirow[t]{2}{*}{ Variables assessed post-DNR } & \multicolumn{2}{|c|}{ By sex } & \multirow[b]{2}{*}{$\mathbf{P}$} \\
\hline & Males & Females & \\
\hline Vital signs & $7.7(3.1)$ & $6.4(16)$ & 0.033 \\
\hline \multirow[t]{3}{*}{ Documentation } & $1.8(3.0)$ & $3.0(1.0)$ & 0.0001 \\
\hline & \multicolumn{2}{|c|}{ By survival } & $P$ \\
\hline & Died & Survived & \\
\hline Vital signs & $8.4(3.3)$ & $6.7(2.0)$ & 0.017 \\
\hline Tests completed & $2.3(1.1)$ & $1.8(0.7)$ & 0.045 \\
\hline
\end{tabular}

Only significantly different scores are shown. Values in parentheses are standard deviation. DNR = Do Not Resuscitate. 
Our study was limited by its small sample size and being a single centre study. However, our results should inspire more research to validate our findings and observe any variation in hospital practices.

\section{Conclusion}

DNR orders are associated with a significant reduction in physicians providing clinical care, which may lead to more refusals of family members to allow DNR orders. Physicians need more insight into the true goals of DNR orders and should not equate them with withholding other therapeutic interventions. DNR orders should not be the first step in a continuum of limitations on care, unless clear goals are established with patients and their families.

Funding: None.

Competing interests: None declared.

\section{Réticence du patient à accepter l'ordre de ne pas réanimer : conséquences sur les soins cliniques}

\section{Résumé}

Contexte : Un ordre de ne pas réanimer doit seulement empêcher l'exécution de la réanimation cardio-respiratoire en cas d'arrêt cardiaque ou respiratoire ; il ne doit pas interférer avec d'autres décisions thérapeutiques.

Objectifs : Étudier les conséquences de l'ordre de ne pas réanimer sur les soins cliniques quotidiens des patients.

Méthodes: Il s'agissait d'une étude de cohorte rétrospective portant sur 72 patients d'un centre de soins tertiaires en Arabie saoudite. Des mesures des soins cliniques quotidiens ont été recueillies pendant deux semaines avant et deux semaines suite à l'émission de l'ordre de ne pas réanimer. Elles ont notamment pris en considération les signes vitaux, les soins infirmiers, les mesures de confort, la documentation, les visites des médecins principaux ou assistants et les examens effectués.

Résultats : La malignité était la catégorie de diagnostic la plus courante (43,1\%). On a constaté une réduction significative des mesures des signes vitaux, des examens effectués, de la documentation et des visites des médecins suite à l'émission des ordres de ne pas réanimer, sans aucun changement au niveau des soins infirmiers et des mesures de confort. Aucune différence n'a été constatée en ce qui concerne le lieu associé à l'ordre de ne pas réanimer (unité de soins intensifs ou service d'hospitalisation), la catégorie de la maladie ou le sexe, mais des différences ont été observées pour la documentation (plus détaillée chez les femmes) et la mesure des signes vitaux (plus fréquente chez les hommes). Les signes vitaux avaient davantage été documentés et plus d'examens avaient été effectués chez les patients qui ont survécu que chez ceux qui sont décédés. L'analyse de régression a montré que la fréquence de la mesure des signes vitaux et des examens effectués suite à l'émission de l'ordre de ne pas réanimer n'était pas liée au sexe, à l'âge, au diagnostic, au temps écoulé entre l'admission et l'émission de l'ordre de ne pas réanimer, ni au lieu de prise en charge du patient. Le délai avant le décès n'était lié qu'au sexe et à la documentation sommaire établie à la suite de l'émission de l'ordre.

Conclusions : L'émission d'un ordre de ne pas réanimer réduisait de manière significative la mesure des signes vitaux, les examens effectués, la documentation et les visites des médecins, mais pas les soins infirmiers ni lesmesures de confort.

$$
\text { ترد أمل الفر حان، منال الحارثي، في قبول أمر "عدم الإنعاش بن موسى، الآثار المترتبة على الرعاف مُقدم، حمدان جحدلي، جنان شامو، عبد الله السياري، سليم باهارون }
$$

$$
\begin{aligned}
& \text { الخلفية: يجب أن يمنع أمر "عدم الإنعاش" أداءَ الإنعاش القلبي الرئوي فقط في حالة تَوَقُّف القَلْب أو التنفس؛ ولا يجب أن يتداخل مع أي قرارات } \\
& \text { أخرى للعلاج. } \\
& \text { الأهداف: دراسة أثر تنفيذ أمر "عدم الإنعاش" على الرعاية السريرية اليومية للمرضى. }
\end{aligned}
$$

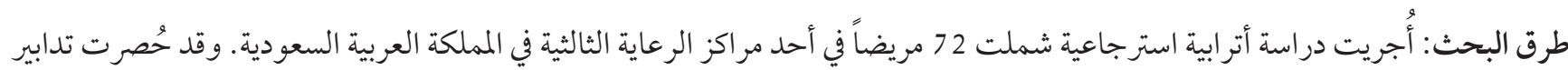

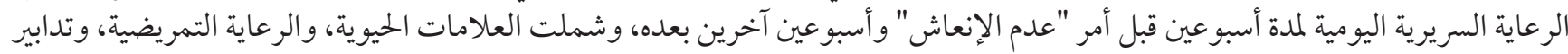

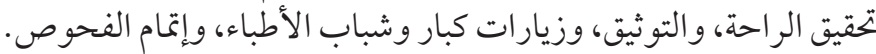

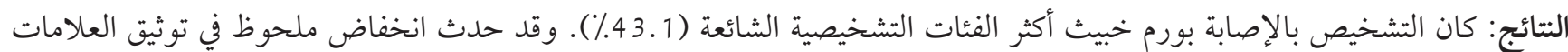

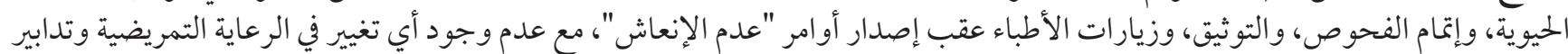

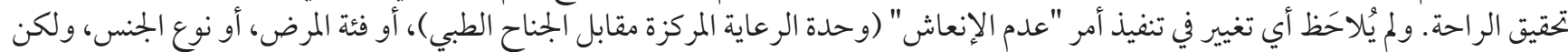




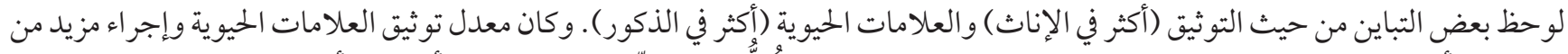

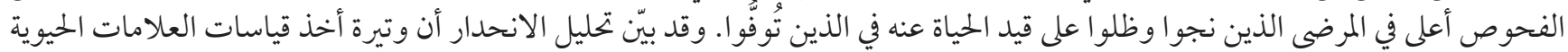

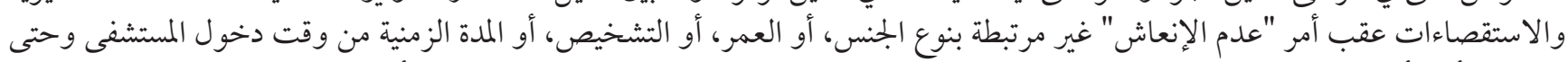

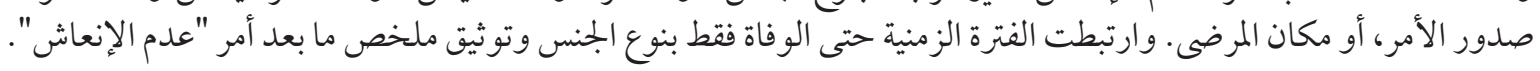

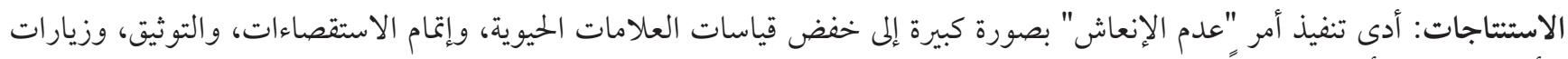

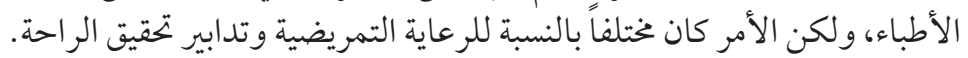

\section{References}

1. President's Commission for the Study of Ethical Problems in Medicine and Biomedical and Behavioral Research. Deciding to forego life-sustaining treatment: a report on the ethical, medical, and legal issues in treatment decisions. 1983.

2. Chen JLT, Sosnov J, Lessard D, Goldberg RJ. Impact of do-not-resuscitation orders on quality of care performance measures in patients hospitalized with acute heart failure. Am Heart J. 2008 Jul 1;156(1):78-84. http://dx.doi.org/10.1016/j.ahj.2008.01.030 PMID:18585500

3. Vetsch G, Uehlinger DE, Zenklusen RZ. DNR orders at a tertiary care hospital-are they appropriate? Swiss Med Wkly. 2002 Apr 20;132(15-16):190-6. http://dx.doi.org/2002/15/smw-09895 PMID:12070784

4. Hemphill JC. Do-not-resuscitate orders, unintended consequences, and the ripple effect. Crit Care. 2007;11(2):121. http://dx.doi. org/10.1186/cc5687 PMID:17338835

5. Mobeireek A. The do-not-resuscitate order: indications on the current practice in Riyadh. Ann Saudi Med. 1995 Jan;15(1):6-9. http://dx.doi.org/10.5144/0256-4947.1995.6 PMID:11656711

6. Lipton HL. Do-not-resuscitate decisions in a community hospital: incidence, implications, and outcomes. JAMA. 1986 Sep 5;256(9):1164-9. PMID:3735651

7. Chang Y, Huang C-F, Lin C-C. Do-not-resuscitate orders for critically ill patients in intensive care. Nurs Ethics. 2010 Jul 1;17(4):445-55. http://dx.doi.org/10.1177/0969733010364893 PMID:20610578

8. Richardson DK, Zive D, Daya M, Newgard CD The impact of early do not resuscitate (DNR) orders on patient care and outcomes following resuscitation from out of hospital cardiac arrest. Resuscitation. 2013 Apr;84(4):483-7. http://dx.doi.org/10.1016/j.resuscitation.2012.08.327. PMID:22940596

9. Kazaure H, Roman S, Sosa JA. High mortality in surgical patients with do-not-resuscitate orders: analysis of 8256 patients. Arch Surg. 2011 Aug;146(8):922-8. http://dx.doi.org/10.1001/archsurg.2011.69 PMID:21502441

10. McNeill D, Mohapatra B, Li JYZ, Spriggs D, Ahamed S, Gaddi Y, et al. Quality of resuscitation orders in general medical patients. QJM Int J Med. 2012 Jan 1;105(1):63-8. https://doi.org/10.1093/qjmed/hcr137

11. Adams SD, Cotton BA, Wade CE, Kozar RA, Dipasupil E, Podbielski JM, et al. Do not resuscitate (DNR) status, not age, affects outcomes after injury: An evaluation of 15,227 consecutive trauma patients. J Trauma Acute Care Surg. 2013 May;74(5):1327-30. http://dx.doi.org/10.1097/TA.obo13e31828c4698 PMID:23609286

12. Chu W, Hynes-Gay P. The influence of DNR orders on patient care in adult ICUs: a review of the evidence. Dynamics. 2002 Winter;13(4):14-21. PMID:12640835

13. Carrión Torre M, Zubizarreta Iriarte E, Sarasa Monreal MM, Margall Coscojuela MA, Asiain Erro MC. Effect of the do-not-resuscitate orders on the critical patient care plan. Enferm Intensiva. 2008 Jan-Mar;19(1):14-22. http://dx.doi.org/10.1016/s11302399(08)72739-1 PMID:18358115

14. Hildén HM, Louhiala P, Honkasalo ML, Palo J. Finnish nurses' views on end-of-life discussions and a comparison with physicians' views. Nurs Ethics. 2004 Mar;11(2):165-78. http://dx.doi.org/10.1191/0969733004ne6810a PMID:15030024

15. Henneman EA, Baird B, Bellamy PE, Faber LL, Oye RK. Effect of do-not-resuscitate orders on the nursing care of critically ill patients. Am J Crit Care. 1994 Nov;3(6):467-72. PMID:7834009

16. Fritz Z, Malyon A, Frankau JM, Parker RA, Cohn S, Laroche CM, et al. The Universal Form of Treatment Options (UFTO) as an alternative to Do Not Attempt Cardiopulmonary Resuscitation (DNACPR) orders: a mixed methods evaluation of the effects on clinical practice and patient care. PLoS One. 2013 Sep 4;8(9):e70977. http://dx.doi.org/10.1371/journal.pone.0070977 PMID:24023718

17. Arabi, Y, Al Sayyari A, Al Moamary M. Shifting paradigm: From "No Code" and "Do Not Resuscitate" to "Goals of Care" policies. Ann Thorac Med. 2018 Apr-Jun;13(2):67-71. http://dx.doi.org/10.4103/atm.ATM_393_17 PMID:29675055 